\title{
Development and Sustainable Tourism Strategies in Red Islands Beach, Banyuwangi Regency
}

\author{
Rita Parmawati ${ }^{1 *}$, Edriana Pangestuti $^{2,3}$, Wike $^{2,3}$, Rizha Hardyansah $^{4}$ \\ ${ }^{1}$ Postgraduate School, University of Brawijaya, Malang, Indonesia \\ ${ }^{2}$ Faculty of Administrative Science, University of Brawijaya, Malang, Indonesia \\ ${ }^{3}$ Women's Studies Program, Postgraduate School, University of Brawijaya, Malang, Indonesia \\ ${ }^{4}$ Master Program of Environmental Sciences, Postgraduate School, University of Brawijaya, Malang, Indonesia
}

\begin{abstract}
Red Islands Beach in Banyuwangi is included in the Provincial Tourism Strategic Area (KSPP). It is an example of the application on tourism management by the community, due to the existence of the community group (POKMAS). Increasing the number of tourists each year causes the need for a sustainable tourism development strategy that also involves the surrounding community to maintain environmental conditions that continue to be sustainable. So, this study aims to formulate a policy of developing sustainable marine tourism on Red Islands Beach in the Banyuwangi Regency. Data was obtained by conducting FGDs and distributing questionnaires to 10 key informants consisting of the Chairperson of Pokmas, the Homestay Manager, the Chairperson of BUMDES in Sumberagung Village, Academics, Ecoranger, Restaurant Managers, and the Management of Waste Banks. The data was analyzed using a SWOT analysis strategy to describe internal factors (IFAS) and external factors (EFAS). The results of the scoring IFAS showed the value of the Strengths (3.337) and weaknesses (2.979), while external factors showed value of opportunity (3.135) and threats (3.224). The strategy that can be applied based on this analysis is Concentric Diversification Strategies. These strategies focus on adding products and services related to the tourism destination, which uses Weakness and Threat (W-T) components. This strategy will overcome weaknesses and minimize threats on Red Islands Beach. Some points that can be carried out in this strategy are increasing human resources, providing education to the community, and negotiating with other interested parties in the Marine Tourism Region of Red Islands Beach.
\end{abstract}

Keywords: Red Island Beach, sustainable tourism, SWOT.

\section{INTRODUCTION}

Tourism has become one of the most developed sectors in Indonesia. According to data, the amount of foreign exchange from the tourism sector continues to increase from 2015 by 12.23 billion dollars to 19.29 billion dollars in 2018 [1]. Also, the number of foreign tourist arrivals increased by $12.58 \%$ in 2018 , thereby being able to increase Gross Domestic Product (GDP), open employment, and improve the level of the Indonesian economy [2].

Tourism in Banyuwangi Regency, East Java, has a rapid development, with destinations that vary from the mountains, culture, and beach, which is the main attraction for tourists when coming to Banyuwangi. The unique landscape of the Banyuwangi Regency $[3,4]$ and coupled with the City Branding of Banyuwangi Regency as Sunrise of Java is a factor in increasing local and foreign tourist visits to Banyuwangi Regency $[5,6]$. The average increase of local and foreign tourists reached $51.4 \%$ and $79.42 \%$ [1]. The

Correspondence address:

Rita Parmawati

Email : rita_parmawati@.ub.ac.id

Address : Postgraduate School, University of Brawijaya, Jl. MT Haryono No. 169, Malang, 65145 development of tourism can increase the PAD of the Banyuwangi Regency, increase the community's economy, and encourage the development of infrastructure around the area $[7,8]$.

The rapid increase in the tourism sector in Banyuwangi has encouraged the government to create a Tourism Development Area (WPP). It consists of three types, namely WPP I (forest area), WPP II (Around the Coast with difficult accessibility), and WPP III (having unique resources natural). One of the WPPs in the Banyuwangi Regency is Red Islands Beach.

Red Islands Beach is managed by the surrounding community that forms the POKJA and cooperates with Perhutani. However, in 2015, the management of Red Islands Beach was handed to the Community Groups (POKMAS). The development orientation of Red Islands Beach is an optimization of community capital and always involves the community in the process [9]. Community participation can be in the process of making decisions related to tourism development plans and the distribution of tourism benefits equally [10].

The development of the Red Island Beach Banyuwangi must be directed towards aspects of 
sustainable tourism. Sustainable tourism is a plan and development that aims to reduce the harmful effects of tourism on the environment, society and economy to achieve ecological (environmental) and social sustainability [11]. In its development, sustainable tourism aims to continue working to improve tourist satisfaction based on the components of sustainable development [12]. A core aspect of sustainable tourism is the participation of the community because harmonizing local people to achieve global goals can help in cultural diversity, environmental conservation, reducing poverty, and increasing respect for the local culture of the community [13-15]. Furthermore, the harmony between the community and sustainable tourism can encourage the creation of good governance and justice in the use of tourism aspects [16].

The previous research showed that to be able to achieve sustainable coastal tourism in Watulimo Trenggalek, strategies that can be used are by (a) increasing promotion, (b) protecting the environment and involving the community, (c) developing tourist attractions which varied and complements the supporting facilities, and (d) improves the quality of Human Resources (HR) [17]. The strategies required by a tourist destination to develop and achieve sustainable tourism are different; this is due to several things, such as the types of attractions, amenities, and accessibility [1]. The rapid development of the tourism sector in Banyuwangi, especially on Red Islands Beach, has led to a balance between the economic and environmental sectors in order to achieve sustainability. So this research aims to formulate a policy of developing sustainable marine tourism in Red Islands Beach, Banyuwangi Regency.

\section{MATERIAL AND METHOD \\ Study Sites}

Red Islands Beach is located in Pancer Hamlet, Banyuwangi Regency $\left(8^{\circ} 36^{\prime} 18.4^{\prime \prime} \mathrm{S}\right.$ and $114^{\circ} 01^{\prime \prime 31.8 " ~ E), ~ w h i c h ~ w a s ~ a p p r o x i m a t e l y ~} 67 \mathrm{~km}$ from the center of Banyuwangi Regency. The coastline was $3 \mathrm{~km}$ long with white, red, and fine sand. Not far from the shoreline, there was a hill, and that was characteristic of Red Islands Beach with a height of approximately $300 \mathrm{~m}$. Tourist activities that can be done in these destinations include surfing, snorkeling, watching sunset and sunrise, and trekking.

\section{Data Collection}

Data collection is done by conducting FGDs and distributing questionnaires to selected informants. Informants in this study consisted of the Chairperson of POKMAS $(n=1)$, Manager of Homestay $(n=2)$, Chairman of BUMDES in Sumberagung Village $(n=1)$, Academics $(n=2)$, Eco ranger $(n=2)$, Restaurant Managers $(n=1)$, and Waste Bank Management $(n=1)$. The FGD process was carried out by explaining the results of a preliminary study of the sustainability status of Red Islands Beach Tourism, which was then continued by distributing questionnaires to informants.

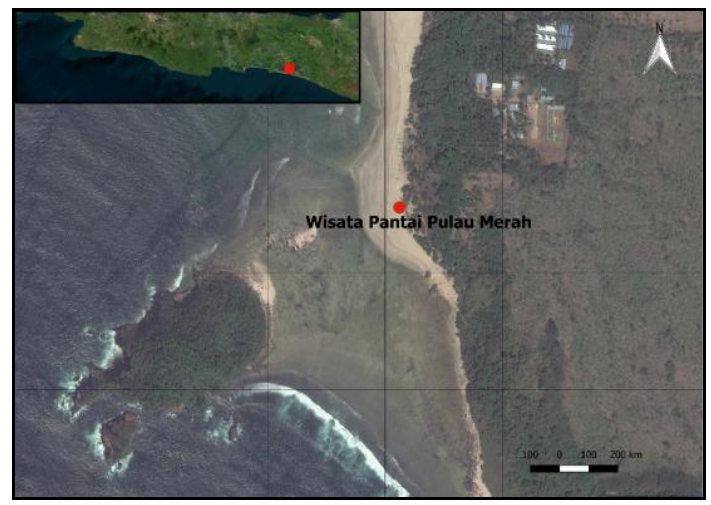

Figure 1. Red Islands Beach, Banyuwangi Regency

Questions consisted of some components:

(1) Strengths: potential resources, supporting infra-structure, community opportunities, and information

(2) Weaknesses: conditions of facilities and infrastructure, large waves, and unique souvenirs

(3) Opportunities: Accessibility, investors and CSR, number of tourists, government planning

(4) Threats: road conditions, availability of public transport, land problems, environmental disruption, and support from related agencies.

Direct observations were also made on the condition of infrastructure. It included the condition of the access road and tourist activities around the Red Islands Beach.

\section{Data Analysis}

This research used SWOT analysis to formulate the strategy for sustainable tourism development in Red Islands Beach. The SWOT analysis model compare opportunities and threats as external factors with strengths and weaknesses as internal factors. Internal factors were analyzed on the IFAS (Internal Strategic Factor Analysis Summary) matrix, and external factors were analyzed on the EFAS (External Strategic Factor Analysis Summary) matrix. SWOT analysis is strategic planning and in presenting the most appropriate data is by using the table, 
so it can analyze the relationships between components $[18,19]$.

There were three stages in the SWOT analysis, namely: (i) calculation of weight and score. For weight had range value interval from 0.00 to 1.00 . After weighting, the rating is given for each component to see the importance of it. After that, scoring had done by multiplying weight and rating, (ii) prediction of strategies based on awareness, and (iii) finding the position of existing conditions in the SWOT quadrant by subtracting the total amount for IFAS and EFAS. For X-axis, the value was obtained by subtracting the total value of Strenght and Weakness. For $Y$ axis, the value was obtained by subtracting the total amount of Opportunity and Threat.

\section{RESULT AND DISCUSSION IFAS and EFAS Matrix}

In this study, the strategy of developing sustainable tourism on Red Islands Beach was obtained from the SWOT analysis. The main data used in this analysis was the data from the questionnaire that was distributed to ten informants, who had also participated in the FGD. The FGD activity aimed to give the community an opportunity in the process of strategy development and sustainability of the Red Islands Beach Banyuwangi. So, it can create harmony between the community and the local government. The results of identification and analysis were arranged as internal and external factors shown in Table 1 and 2.

Internal factor matrix consisting of strengths and weaknesses, which are a description of the factors that affect the sustainability of tourist destinations (Table 1). Internal analysis is quite effective for analyzing tourist destinations [20]. The strength component of developing Red Islands Beach as sustainable tourism is 3.332 . While weaknesses indicate the value of 2.979 , so, from internal factors, the development of Red Islands Beach is already classified as good and strong. The formulation of the right strategy is to maintain strengths and overcome existing weaknesses.

The opportunity and threat component can significantly influence the development and damage of future tourist destinations. The opportunity component of the external matrix shows a value of 3.135 and has a threat value of 3.224 (Table 2). This situation indicates the opportunity to develop marine tourism in Red Islands Beach is still small compared to the existing threats.
Tabel 1. Matrix of IFAS

\begin{tabular}{|c|c|c|c|}
\hline \multirow{2}{*}{$\begin{array}{l}\text { Internal Factors } \\
\text { Strength }\end{array}$} & \multicolumn{3}{|c|}{ Value } \\
\hline & $\mathbf{W}$ & $\mathbf{R}$ & $\mathbf{S}$ \\
\hline Beautifull scenery & 0.051 & 3.4 & 0.172 \\
\hline Has other tourism destination & 0.048 & 3.2 & 0.154 \\
\hline Local wisdom & 0.053 & 3.5 & 0.186 \\
\hline Dragon fruit potential & 0.051 & 3.2 & 0.162 \\
\hline Seafood avaliable & 0.051 & 3.1 & 0.157 \\
\hline Playground & 0.056 & 3.2 & 0.178 \\
\hline Parking services & 0.059 & 3.5 & 0.208 \\
\hline Public toilet and prayer room & 0.058 & 3.3 & 0.192 \\
\hline Homestay & 0.058 & 3.3 & 0.192 \\
\hline Information boar & 0.057 & 2.9 & 0.165 \\
\hline Online promotion & 0.061 & 3.3 & 0.200 \\
\hline There are POKMAS & 0.063 & 3.4 & 0.215 \\
\hline Business opportunities & 0.066 & 3.6 & 0.236 \\
\hline Environmental awarness & 0.067 & 3.4 & 0.228 \\
\hline Ecoranger and trash bank & 0.068 & 3.4 & 0.232 \\
\hline Tawang alun shrine & 0.067 & 3.3 & 0.221 \\
\hline Surfing and snorkeling spot & 0.068 & 3.5 & 0.239 \\
\hline Sub Amount & 1 & & 3.337 \\
\hline \multicolumn{4}{|l|}{ Weakness } \\
\hline Big wave & 0.120 & 2.6 & 0.313 \\
\hline Lack of souvenir shop & 0.135 & 3.2 & 0.433 \\
\hline Lack toilet & 0.147 & 3.2 & 0.469 \\
\hline Lack in trash management & 0.150 & 3.3 & 0.496 \\
\hline Not optmalized the dragon fruit & 0.147 & 2.8 & 0.411 \\
\hline There'isnt specific souvenir & 0.150 & 2.8 & 0.421 \\
\hline Lack in dragon fruit product & 0.150 & 2.9 & 0.436 \\
\hline Sub Amount & 1 & & 2.979 \\
\hline \multicolumn{4}{|c|}{ Notes: $\mathrm{W}=$ weight, $\mathrm{R}=$ relative, $\mathrm{S}=$ Score } \\
\hline \multicolumn{4}{|c|}{ Table 2. Matrix of EFAS } \\
\hline External Factor & & /alue & \\
\hline Opportunity & $\mathbf{W}$ & $\mathbf{R}$ & $\mathbf{S}$ \\
\hline Easy Accessibility & 0.117 & 3.1 & 0.364 \\
\hline $\begin{array}{l}\text { Government participation in } \\
\text { planning }\end{array}$ & 0.114 & 3.1 & 0.354 \\
\hline CSR Program & 0.092 & 2.7 & 0.249 \\
\hline Accessible geographic site & 0.133 & 3.3 & 0.440 \\
\hline One of KSPP & 0.137 & 3.3 & 0.450 \\
\hline There is Airport & 0.140 & 3.5 & 0.489 \\
\hline There is inverstor & 0.117 & 2.9 & 0.341 \\
\hline Highest number of tourists & 0.149 & 3.0 & 0.448 \\
\hline Sub Amount & 1 & & 3.135 \\
\hline \multicolumn{4}{|l|}{ Threat } \\
\hline $\begin{array}{l}\text { The road narrowed at some } \\
\text { point }\end{array}$ & 0.108 & 3.4 & 0.368 \\
\hline There isn't public trasnportation & 0.097 & 3.1 & 0.301 \\
\hline $\begin{array}{l}\text { Located within the mine map } \\
\text { area }\end{array}$ & 0.108 & 3.6 & 0.390 \\
\hline $\begin{array}{l}\text { Tourist not aware about } \\
\text { environment }\end{array}$ & 0.114 & 3.4 & 0.387 \\
\hline Located within Perhutani area & 0.092 & 3.0 & 0.275 \\
\hline There are land issues & 0.117 & 3.2 & 0.373 \\
\hline Environmental disturbances & 0.119 & 3.2 & 0.382 \\
\hline Have traffic when high season & 0.117 & 3.0 & 0.350 \\
\hline Not yet supported by Tourism & 0.128 & 3.1 & 0.396 \\
\hline
\end{tabular}
Office

\begin{tabular}{lrl}
\hline Sub Amount & 1 & 3.224 \\
\hline Notes: $W=$ weight, R=relative, S=Score &
\end{tabular}


Internal and external factors are essential components because these two factors can explain the general picture of the condition of a tourist destination or organization so that it can create an appropriate and optimal management strategy to be implemented [21,22]. The results of scoring in Table 1 and 2 show that the value of external factors is more significant than internal factors. It is because external factors have more influence compared to internal factors [23].

\section{Grand Strategy Matrix}

The results of the calculation of the difference between the components in internal and external factors were then used to determine the coordinates in determining the development strategy of the Red Islands Beach marine tourism using the grand strategy matrix. Horizontal axis value (X-axis) is the value of the difference from internal factors, namely strengths and weaknesses $(X=3.332-2.979=0.353)$. Meanwhile, the vertical axis (Y-axis) is the value of the difference in external factors, namely opportunities and threats $(Y=3.134-3.223=-0.089)$. The coordinate points were obtained $0.353 ;-0.089$. The location of these coordinates will determine the right strategy to be implemented under the description of internal and external factors on Red Islands Beach (Fig. 2).

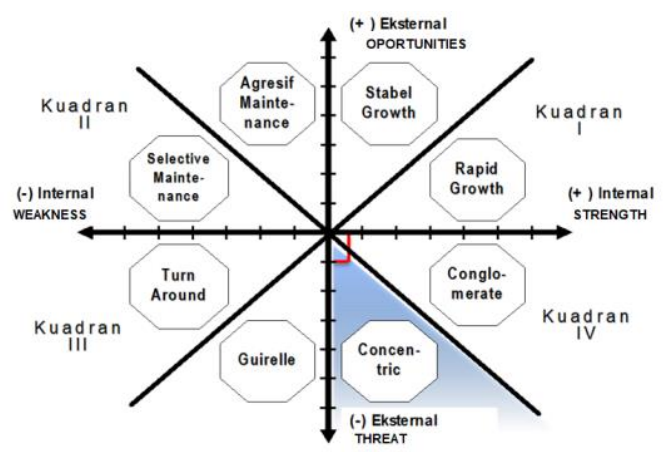

Figure 2. Grand Staretgy Matriks of SWOT

Figure 2 shows that the strategy that can be implemented in the development and sustainable tourism is quadrant IV, the concentric strategy. Quadrant IV indicates that this tourist destination has a competitive position but is in a scope that makes it challenging to develop, so the right strategy for quadrant IV is concentric [19]. A concentric strategy is a strategy that maximizes the power to overcome the threats they have. This strategy is carried out by building tourist destinations that are compatible with products, technology, and markets. This strategy is suitable for tourist destinations with a threat but has an opportunity to develop [24].

\section{Red Islands Beach Development and Sustainable Tourism Strategies}

Red Islands Beach has the advantage of having spots for snorkeling and surfing. Snorkeling, scuba diving, and surfing become one of the essential components in marine tourism [25-29]. Snorkeling activities can provide incentives for local people and recreational service providers to protect coral reef ecosystems because the presence of swimmers can be a factor in the degradation of coral reef ecosystems [25]. It also acts as conservation efforts [28], able to increase public awareness to protect the environment [29] and participate in ecosystem monitoring activities [30]. In addition to the existence of a new airport in Banyuwangi, which has an international standard, making the Red Islands Beach a destination by foreign tourists who think that surfing is a necessity or a culture [29]. The theory stated, there is a relationship between tourists' perceptions of people's ability to explore their unique habits, and this can make tourists come to visit again [15].

The uniqueness of the landscape with various tourist activities that can be done makes the Red Islands Beach into the KSPP. So, it is very appropriate if it is developed into sustainable tourism to maintain the condition of the ecosystem. Besides, the government must also struggle to make plans related to tourism development. It relates to the current to improve the environment of tourism activities carried out voluntarily and based on community regulations [31]. Local identity and culture must also be maintained in the planning and implementation process of tourism development, and the steps that can be taken are to provide training to the community, reduce waste by initiating the community so that it can be recycled again [32].

Business opportunities on Red Islands Beach can encourage community economic improvement, increase employment, and be able to open new business [2]. It is because tourism is categorized as an agent of change in the economic and social sectors, but in its development, it takes the participation of local governments to be able to provide training, help the planning process, and the promotion [33].

Public awareness of the environment around Red Islands Beach is one of the substantial supporting factors in the development of sustainable tourism, which is indicated by the existence of eco rangers and waste banks. However, even though a waste bank is available, 
the process in it is still in the sorting stage and has not yet reached the stage of processing or recycling into a product that has economic value. Souvenirs produced by recycling waste into a product of economic value can increase the curiosity of tourists to buy or try to make and add to the uniqueness of a tourist destination [32]. The existence of attractive products and services in the tourism sector and nature and cultural conservation process carried out by the community can increase the competitiveness of tourist destinations [34,35].

\section{Strategy to Counter the Obstacle}

The position of Red Islands Beach is on the map of the mining area, where this can create conflict in the future between the private sector and the community. The environmental impact produced by mining activities also affects the environmental conditions around the tourist area. Mining activities around tourist destinations have an impact on the ecosystem and socio-economic community. Also, the existence of mining activities can cause protests by the local community because it can threaten the tourism sector by reducing the beauty of the tourist destination, so that there is a need for consultation with stakeholders and the local community. It must involve the local community in the process of decision making in every step of its development [36]. By doing this, it can create cooperation between the community and local companies that can support the development of tourism [37].

The strategy that can be applied based on this analysis is Concentric, which uses Weakness and Threat (W-T) components to overcome weaknesses and minimize threats on the Red Islands Beach. This strategy consists of:

(1) Improving the quality of human resources in the field of tourism. Thus, they can create unique products based on Red Islands Beach potential.

(2) Establish tourism management of community, government, and academics

(3) Educating the community to help in preserving the environment by involving tourists to recycle the waste that has been sorting. It can create more attractions from the process of making crafts with recycled waste.

(4) Trying to negotiate with Perhutani, so the area will be owned by the community and become independent land.
(5) Negotiating with the local government of Banyuwangi Regency and PT. BSI as the owner of mining activity in the area, in order to continue and to be able on managing the Red Islands Beach into a marine tourism area.

\section{CONCLUSION}

This research contributes to the planning and development of strategies to achieve sustainable tourism by implementing synergy between the community, stakeholders, government, and private companies related specifically to marine tourism. The development strategy that can be carried out in the Marine Tourism of Red Islands Beach, Banyuwangi Regency, is the Concentric Diversification Strategy or WT (Weakness-Threat) strategy. This strategy is used to overcome the weaknesses and minimize threats that exist on Red Islands Beach. In this strategy, several points can be made, namely by increasing human resources, providing education to the community, and negotiating with other interested parties in the Red Islands Beach Tourism Area.

\section{ACKNOWLEDGEMENT}

The authors would like to thank LPPM UB for the Beginner Research Grants (HPP) program, the Banyuwangi Regency Government, and the people in Sumberagung Village who have given permission and provided accommodation during the study.

\section{REFERENCES}

[1] BPS-Statistic Center Indonesia. 2019. Statistik Indonesia 2019. BPS-Statistic Center Indonesia. Jakarta.

[2] Mariyono, J. 2017. Determinats of Demand for Foreign Tourism in Indonesia. Jurnal Ekonomi Pembangunan 18(1), 82-92.

[3] Mensah, I. and A. Ernest. 2013. Community participation in ecotourism: the case of Bobiri Forest Reserve and butterfly sanctuary in Ashanti Region of Ghana. American Journal of Tourism Management 2(1A), 34-42.

[4] Blaj, R. 2014. Ecotourism and nature tourism - components of a sustainable management of forests. Journal of Horticulture, Forestry, and Biotechnology 18(4), 51-54.

[5] Sari, I. K. S. P., E. Pangestuti, Supriono. 2019. Analisis dampak city branding terhadap kunjungan wisatawan ke Kabupaten Banyuwangi (studi pada Dinas 
Kebudayaan dan Pariwisata Kabupaten Banyuwangi). Jurnal Administrasi Bisnis 72(1), 63-72.

[6] Jojic, S. 2018. City branding and the tourist gaze: city branding for tourism development. European Journal of Social Science Education and Research 5(3), 150160.

[7] Rahma, F. N. and H. R. Handayani. 2013. Pengaruh jumlah kunjungan wisatawan, jumlah obyek wisata dan pendapatan perkapita terhadap penerimaan sektor pariwisata di Kabupaten Kudus. Diponegoro Journal of Economics 2(2), 1-9.

[8] Tribe, J. 2011. The economics of recreation, leisure, and tourism. $4^{\text {th }} \mathrm{Ed}$. Routledge. London.

[9] Al Haq, D. I. M., D. Yulisetiarini, G. A. Wulandari. 2016. Strategi pengembangan wisata Pulau Merah di Kabupaten Banyuwangi. Artikel Ilmiah Mahasiswa. State University of Jember. Jember.

[10] Sutresna, I. B., U. Suyana, I. A. Saskara, and N. P. Setyari. 2019. Community based tourism as sustainable tourism support. Russian Journal of Agricultural and SocioEconomic Sciences 94, 70-78. DOI: 10.18551/rjoas.2019-10.09.

[11] Pan, S. Y., M. Gao, H. Kim, K. J. Shah, S. L. Pei, and P. C. Chiang. 2018. Advances and challenges in sustainable tourism toward a green economy. Science of the Total Environment 635, 452-469.

[12] Sharpley, R. 2000. Tourism and sustainable development: exploring the theoretical divide. Journal of Sustainable Tourism 8, 19.

[13] Simpson, M. C. 2008. Community benefit tourism initiatives: a conceptual oxymoron? Tourism Management 29, 1-8.

[14] Lee, T. H., and F. H. Jan. 2019. Can community-based tourism contribute to sustainable development? evidence from resident's perception of the sustainability. Tourism Management 70, 368-380.

[15] Han, H., T. Eom, A. Al-ansi, H. B. Ryu, W. Kim. 2019. Community-based tourism as a sustainable direction in destination development: an empirical examination of visitor begaviors. Sustainability 11(2864), 114.

[16] Dangi, T. B. and T. Jamal. 2016. An integrated approach to "sustainable community-based tourism". Sustainability 8(475), 1-32.
[17] Parmawati, R., A. S. Leksono, B. Yanuwiadi, and A. S. Kurnianto. 2017. Exploration of marine tourism in Watulimo, Trenggalek Regency: challenges, potentials, and development strategies. Journal of Indonesian Tourism and Developmental Studies 5(3), 175-184.

[18] Jackson, S. E., A. Joshi, N. L. Erhardt. 2003. Recent research on team and organizational diversity: SWOT analysis and implication. Journal of Management 29(6), 801-830.

[19] Sariisik, M., O. Tukay, and O. Akova. 2011. How to manage yacht tourism in Turkey: a SWOT analysis and related strategies. Procedia Social and Behavioral Sciences 24, 1014-1025.

[20] Zhang, Q. 2012. Research on Tourist Attractions Performance Promoting Method Based on the SWOT Analysis Method. IERI Procedia 1, 254-260.

[21] Pahl, N. and A. Richter. 2009. SWOT Analysis-idea, methodology and a practical approach. Grin Verlag. Germany.

[22] David, F. R. 2003. Strategic management concepts and cases, $9^{\text {th }} \mathrm{Ed}$. Pearson Education. USA.

[23] Carpenter, M. A. and W. G. Sanders. 2007. Strategic management: a dynamic perspective concepts and cases. Pearson/ Prentice Hall. New jersey.

[24] Ganguli, S. and H. E. Ahmed. 2017. A qualitative analysis of Singapore's medical tourism competitiveness Subhadra Ganguli. Tourism Management Perspectives 21, 7484.

[25] Salim, N., A. L. Abdullah, and B. Mohamed. 2013. Tourist satisfication on snorkeling activity in Redang Island. $12^{\text {th }}$ Asia-Pacific Forum for Graduate Students' Research in Tourism - Challenging Conventions in Research.

[26] Lucrezi, S. and M. Saayam. 2017. Sustainable scuba diving tourism and resource use: perspective and experiences of operators in Mozambique and Italy. Journal of Cleaner Production 168, 632-644.

[27] Reis, P. and J. P. Jorge. 2012. Surf tourism: segmentation by motivation and destination choice. Proceedings of the $2^{\text {nd }}$ International Conference on Tourism Recreation. Peniche.

[28] Biggs, D., N. C. Band, and C. M. Hall. 2012. Lifestyle values, resilience, and naturebased tourism's contribution to conservation on Australia's Great Barrier 
Reef. Environmental Conservation 39, 370379.

[29] Biggs, D., C. M. Hall, and N. Stoeckl. 2012. The resilience of formal and informal tourism enterprises to disaster: reef tourism in Phuket, Thailand. Journal of Sustainable Tourism 20, 645-665.

[30] Cerrano, C., M. Milanese, and M. Ponti. 2016. Diving for science - science for diving: volunteer scuba divers support science and conservation in the Medeterranean Sea. Aquatic Conservation: Marine and Freshwater Ecosystems 27(2), 303-323.

[31] Aall, C. 2014. Sustainable tourism in practice: promoting or perventing the quest for sustainable development? Sustainability 6, 2562-2583.

[32] Kisi, N. A. 2019. Strategic approach to sustainable tourism development using the A'WOT Hybrid Method: a case study pf Zonguldak, Turkey. Sustainability 11(964), 1-19.

[33] Nongsiej, P. and S. R. Shimray. 2017. The role of entrepreneurship in tourism industry: an overview. National Seminar on Entrepreneurial Opportunities for Educated Youth in Global Business.

[34] Torabian, P. and S. M. Arai. 2013. Tourist perceptions of souvenir authenticity: an exploration of selective tourist blog. Current Issues in Tourism 19(7), 697-712.

[35] Romao, J., J. Guerreiro, and P. M. M. Rodrigues. 2017. Territory and sustainable tourism development: a space-time analysis on European regions. Region 4, 1-17.

[36] Leonard, L., and T. Lebogang. Exploring the impact of mining on tourism growth and local sustainability: the case of Mapungubwe Heritage Site, Limpopo, South Africa. Sustainable Development 26(10), 206-216.

[37] Graci, S. 2013. Collaboration and partnership development for sustainable tourism. Tourism Geographies 15, 25-42. 